\title{
Electrical Resistivity Imaging of a Thin Clayey Aquitard Developed on Basement Rocks in Parts of Adekunle Ajasin University Campus, Akungba-Akoko, South-western Nigeria
}

\author{
Muslim B. Aminu \\ Department of Earth Sciences, Adekunle Ajasin University, Akungba-Akoko, Nigeria \\ Corresponding author: \\ Muslim B. Aminu, Department of Earth Sciences, Adekunle Ajasin University, Akungba-Akoko, PMB 001, Ondo \\ State, Nigeria \\ E-mail: muslimaminu@gmail.com
}

(received in December 2014; accepted in March 2015)

In this study, 2-dimensional electrical resistivity surveying has been used to reveal the nature and development of a thin clayey aquitard on basement complex rocks of the Adekunle Ajasin University campus, Akungba-Akoko south-western Nigeria. The aim was to evaluate the occurrence, geometry and groundwater viability of this clayey aquitard as an alternative source of water supply on the Campus. Prior, a hand-dug well, which supplied moderate volumes of water all year round, had been abstracting water from this aquitard.

Three east-west geo-electric traverses were surveyed using the dipole-dipole array configuration with an electrode separation of $5 \mathrm{~m}$ and a maximum dipole length of $45 \mathrm{~m}$. Each of the three traverses was $60 \mathrm{~m}$ long. The observed field data were inverted for subsurface 2D resistivity structure using a commercially available 2.5D finite element modelling inversion software.

The clayey aquitard is imaged to exist as low resistivity response patterns which have developed in elongated trough-like depressions created as a result of deep weathering of the feldspar and amphibolite-rich sections of the basement rocks of the area. This clayey layer reaches a thickness of $10 \mathrm{~m}$ at the southern end of the survey and in some sections is compartmentalised into segments by basement rocks which have better resisted weathering. Where the topographic slope of the ground surface is low enough as to allow the accumulation of run-off, the clayey aquitard develops into visible marshy swamps. Although, clayey aquitards of this nature supply water at low rates, their capacity to store high volumes and to be available all-year-round could prove essential to ameliorating acute water shortages experienced in the area during the dry season.

Keyword: Akungba-Akoko, clayey aquitard, electrical resistivity imaging, deep weathering troughs.

\section{Introduction}

Water is essential to people and the largest available source of fresh and potable water lies underground. Increased demands for water have stimulated development of underground resources (Todd, 1980; Nwankwoala, 2011). People require water for several purposes: domestic, agricultural and industrial. However, available surface flows are frequently subject to seasonal variations in flow volume and are highly susceptible to contamination from various domestic, agricultural and industrial activities, thus rendering them inadequate both in quantity and quality to meet demands. Therefore, groundwater resources must be developed and exploited in a sustainable manner (Hamil \& Bell, 1986; Venkateswarlu, Jayasankar, \& Saradhi, 2014). 
In basement complex regions such as the southwestern region of Nigeria, the provision of water for domestic and industrial consumption frequently relies solely on the exploitation of groundwater residing in fractures and weathered overburden. Major faults and fracture systems in the bedrock serve as groundwater collectors and pathways (Lines et al., 2012; Mohamed, Brasse, Abdelgalil, \& Kheiralla, 2012; Moustafa, Ibrahim, Elawadi, Metwaly, \& Al Agami, 2012; Aminu, Akande, \& Ishola, 2014b) during the rainy season and continually recharge the weathered overburden during the dry season. Unfortunately, overburden thicknesses are frequently very thin to prevent long periods of storage. Although extensive tectonic activities have resulted in the creation of several generations of fractures, these sources are unreliable and usually dry-up totally during the dry season (Offodile, 1983). They also frequently contain greater amounts of contaminants (Aminu, Ajayi, \& Adelabu, 2014a). This situation is particularly evident on Adekunle Ajasin University campus where a surge in student enrolment in recent times has placed heavy demands on available water resources in and around the campus. Prior, the strategy of the University at meeting this demand was to embark on an aggressive campaign of drilling several boreholes at various locations within the University campus. However, the lengthening of the dry season spell, rising mean temperature (Bello et al., 2012) and the continuous increase in demand for potable water have led to dwindling and insufficient production from the boreholes. This situation has led the University management to rationing water on campus during the dry season. The need to find other sources with the capacity to store larger volumes of water and year-through availability therefore becomes acute.

In this vein, this study presents the result of geo-electrical imaging of a thin clayey aquitard, developed over part of the basement rocks within the University campus. This clayey aquitard apparently stores water during the prolonged rainy season and releases the same water at a very slow rate to a nearby hand-dug well. Although, the rate of release is low and the well cannot be exploited at a high rate, the layer provides a continuous supply of groundwater, which remains available well through the year. The aim of this study was to evaluate the nature and development of this aquitard and its groundwater viability as an alternative palliative source of water supply at the university campus.

Electrical resistivity methods are versatile tools at detailing geologic factors favourable to groundwater resource accumulation and migration, recharge and discharge, and vulnerability (LaBrecque, Ramirez, Daily, Binley, \& Schima, 1996; Zume, Tarhule, \& Cristenson, 2006; Rizzo, Colella, Lapenna, \& Piscitelli, 2004; Nguyen, Garambois, Jongmans, Pirard, \& Loke, 2005). Electrical resistivity methods take advantage of the fact that different earth materials respond to the passage of electrical current in different ways; some being more permissive of the flow of the current through them than others (Reynolds, 1997; Loke, 2000). Key factors which determine the ease or otherwise of current flow through earth materials include lithology, the amount of connected void spaces and the electrical characteristics of the fluid saturating these void spaces. Of all factors, the nature of the fluid (in most cases water) is the most significant factor. Earth materials are generally resistive and the presence of groundwater serves to lower resistivity. In electrical resistivity imaging, the subsurface is charged by means of two current electrodes at the ground surface and the resulting resistivity response of the earth is measured via another set of two potential electrodes. The response obtained is used along with the layout configurations of the survey to create an image of the subsurface within the survey area (Aminu et al., 2014b).

Robineau, Join, Beauvais, Parisot, \& Savin (2007), utilised electrical resistivity tomography (ERT) to study the nature of a thick regolith within supergene nickel ore deposit developed on ultramafic rocks in New Caledonia (southwest Pacific). The ERT sections clearly mapped lateral lithological boundaries in the thick overburden. High resistivity zones were interpreted as weathering resistant basement ridges while low resistivity zones were interpreted as swales of deep weathering saprolite. The results of the ERT imaging were verified by borehole log data at several locations within the study area. Further, Sjödahl, Dahlin, Zhou, \& Johansson (2002) conducted a modelling experiment aimed at improving long term monitoring routines at two embankment dams in the north of Sweden and to increase understanding when interpreting existing data from these dams. The monitoring system is based upon the use of electrical resistivity measurements. The study involved the evaluation of the influence from 3D effects due to specific dam geometry and comparison of various electrode array configurations. They developed software for modelling resistivity distribution in earth embankment dams. Frid, Liskevich, Doudkinski, \& Korostishevsky (2007), utilised electrical resistivity imaging along with two drilled wells to evaluate the boundary of a landfill boundary in the northern Israel. The challenge of the study stemmed from the difficulty in determining the boundary between the landfill body bottom, which is heavily saturated with leachates, and the underlying layers of highly water saturated nonconsolidated clays. Statistical analysis of the electrical resistivity imaging data was utilised to determine the landfill/subsoil boundary. Variations in standard deviation and confidence interval of a set of resistivity data measured in the landfill body were found to be significantly larger than those in underlying clays.

\section{Materials and methods}

\section{$2.1 \quad$ Site of investigation}

Adekunle Ajasin University is located in Akungba-Akoko, Akoko south-west local 
government area in the extreme north-eastern region of Ondo State, Nigeria (Fig. 1). Akungba-Akoko lies between longitudes $05^{\circ} 43^{\prime}$ and $05^{\circ} 47^{\prime}$, and latitudes $07^{\circ} 27^{\prime}$ and $07^{\circ} 31^{\prime}$. The physiographic disposition of the area consists of a gently sloping central low lying region surrounded in a perimeter-like fashion by high rising granitic hills to the north, west and south-east. Topographic relief is generally greater than $345 \mathrm{~m}$ above sea level with perimeter hills rising up to $420 \mathrm{~m}$ above sea level. The area is underlain by rocks of the migmatite-gneiss complex of the basement rocks of the south-western Nigeria (Rahaman, 1989). Specifically, the suite of rocks consists of biotite-rich grey gneiss, granite gneiss and lesser amounts of charnockites. The area is drained by few seasonal streams which generally take their course from high reliefs in the northeast. Regolith development in the area is apparently thin. This is appreciated from visual reconnaissance evaluation of the area; the fresh basement rocks frequently outcrops at short intervals in several parts of the area. As other rocks of the Precambrian basement complex of southwestern Nigeria, the rocks of the Akungba-Akoko area have undergone at least two episodes of tectonic deformation. This has engendered the development of series of fractures and complex minor folds. Drainage courses are generally controlled by more major and persistent fracture paths.

The survey site is in the western campus of Adekunle Ajasin University. It runs in a north-south direction between the Faculty of Science building and the Education Trust Fund Lecture Theatre Quadrangle, straddles adjacent to the Intercontinental Bank Auditorium and terminates downslope towards the Faculty of Education Complex. This area exists as a narrow gently sloping depression, which terminates in swamp clays to the south. Slightly north-west of the Intercontinental Bank Auditorium, there exists a hand-dug well with a reputation for providing water all-year-round. This well sits within the surveyed area and presumably abstracts water from the clayey aquitard.

\subsection{Methodology}

Taking cognizance of buildings and other obstructions within the campus, three (3) traverses trending roughly east-west were occupied (Fig. 1). Each traverse was $60 \mathrm{~m}$ in length and was laid across the narrow gentle depression where the clayey aquitard is known to exist and envisaged to span. 2D electrical resistivity data were collected using ABEM 1000 Terrameter unit, provided by the Department of Earth Sciences of Adekunle Ajasin University. The dipole-dipole technique was utilised to take advantage of its superior capacity to combine both lateral and vertical imaging relative to other techniques and the relative ease of implementation compared to the pole-dipole technique (Telford, Geldart, Sheriff, \& Keys, 1990; White, Collins, \& Loke, 2003) within the area. The latter requires (theoretically) the location of one current electrode at infinity, a condition difficult to implement within urbane environments due to obstructions from buildings and constant vehicular and human movement. Dipole spacing on all traverses was $5 \mathrm{~m}$ and a maximum dipole spread of $45 \mathrm{~m}$ was attained. Data were collected in the month of October towards the end of the rainy season.

The field resistivity data were processed for spikes and inverted using a 2.5D finite element modelling inversion algorithm known as DIPROfWIN developed by Dr. Jung Ho Kim of Korea Institute of Geoscience and Mineral Resources (KIGAM). DIPROfWIN utilises the active constraint balancing scheme to determine the spatially varying Lagrangian multipliers for the least-squares inversion algorithm (Yi and Kim, 1998). DIPROfWIN inverts the data by minimising the difference between an initial synthetic model of subsurface resistivity distribution and the observed resistivity fields until a reasonable fit is achieved. The result is deemed suitable once the mismatch error drops below $5 \%$. The software finally outputs to a display window three images, (1) the observed field data pseudosection, (2) the computed theoretical data pseudosection and (3) the inverted subsurface $2 \mathrm{D}$ resistivity structure. The output inverted resistivity images along the three traverses were interpreted for subsurface geology.

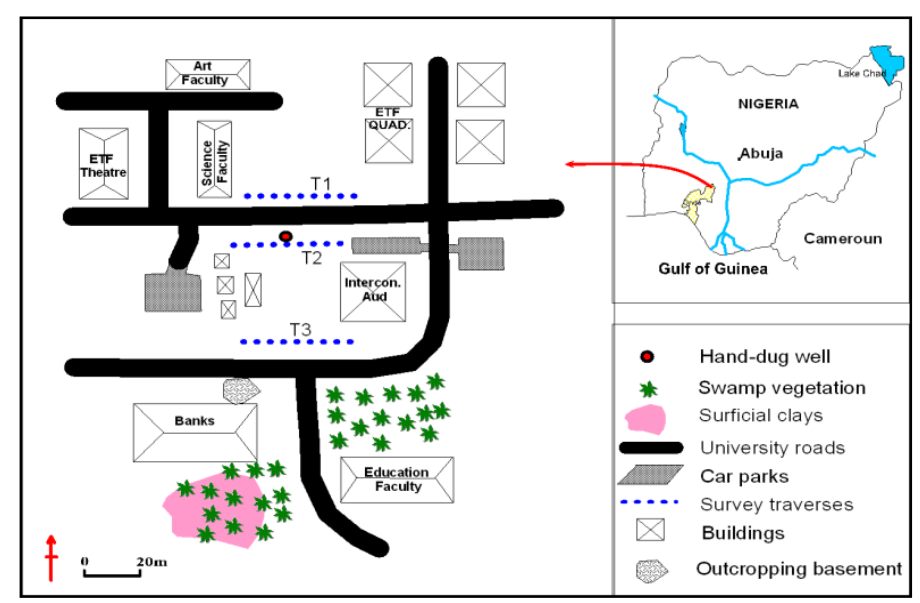

Figure 1. Location map of the survey area. Survey traverses are indicated in dotted blue lines. 


\section{Results}

Figure 2 displays a composite image, which consists of the observed field data pseudo-section, the computed theoretical data pseudo-section and the inverted 2D resistivity structure for Traverse 1 (T1) location. The resistivity distribution patterns in both the observed field data pseudo-section and the theoretical data pseudo-section are practically identical. This is a measure of robustness of the inversion.

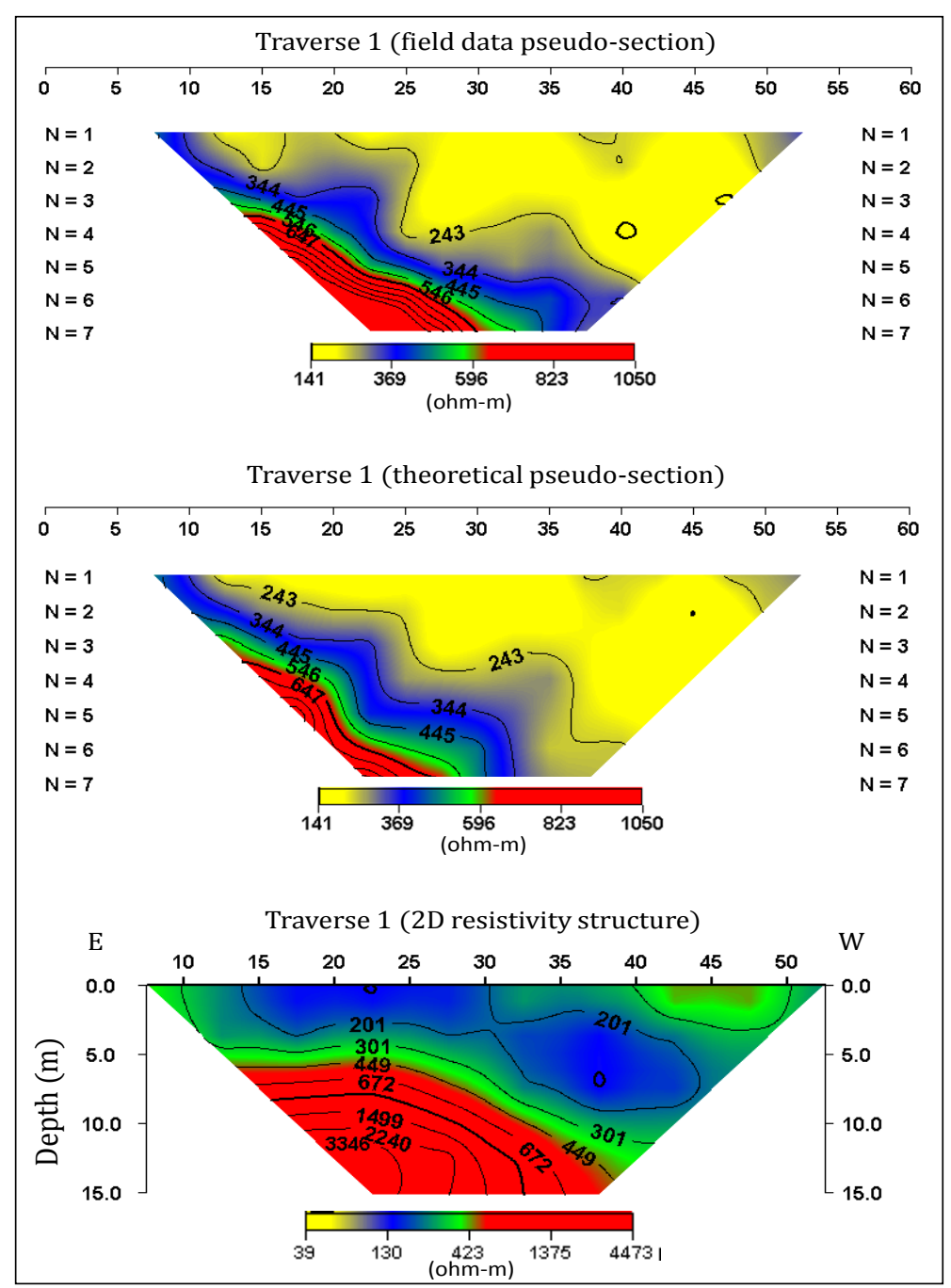

Figure 2. Composite plot of pseudo-sections of the results of $2 D$ resistivity inversion beneath Traverse 1: (a) observed resistivity data, (b) computed resistivity distribution, and (c) inverted resistivity structure. The low resistivity response clayey aquitard extends laterally at the surface for the eastern regions of the traverse but plunges at about $33^{\circ}$ in the west where the basement rocks have apparently suffered deeper weathering.

The subsurface resistivity response beneath the T1 profile can be divided into three patterns. The first pattern is a continuous low resistivity response with resistivities in the range of $110-260 \mathrm{ohm}-\mathrm{m}$. This pattern occurs at the surface for most of the traverse, specifically from $10 \mathrm{~m}$ along the traverse (in the eastern end) until about $35 \mathrm{~m}$, and extends to a depth of about $4.8 \mathrm{~m}$. Further to the west, this pattern does not outcrop but occurs at deeper levels. The pattern extends from about 1-4 m below the ground surface to depths ranging from $5-11 \mathrm{~m}$ from the $35 \mathrm{~m}$ mark until $45 \mathrm{~m}$. This confers on the pattern a high westward dip at about $33^{\circ}$ in the western region of the traverse. This pattern is interpreted to represent the clayey water filled aquitard within the study area. The second pattern is an extensive consistently high resistivity response pattern with resistivity generally in excess of $480 \mathrm{ohm}-\mathrm{m}$. The response pattern exists throughout the traverse at depth. Its upper surface is flat at around $6 \mathrm{~m}$ depth below the ground surface in the eastern section of the traverse but dips to depths beyond $10 \mathrm{~m}$ in the western end of the traverse. This resistivity response represents the shallow unweathered basement rock within the study area. The third response pattern consists of two signatures with resistivity between 300 and $410 \mathrm{ohm}-\mathrm{m}$. The first of the two signatures occurs at the ground surface in the western section of the traverse between the positions of $40 \mathrm{~m}$ and $50 \mathrm{~m}$. It extends downwards to a depth of $3 \mathrm{~m}$. This signature represents dry surficial topsoil which is observable in the area. The second signature lies as a thin layer, generally not thicker than $1.2 \mathrm{~m}$, which separates between the low resistivity clayey aquitard response above and the high resistivity unweathered basement response below. This second signature is interpreted to 
represent the zone of active weathering lying above the fresh basement.

Traverse 2 (T2) is roughly $15 \mathrm{~m}$ south of Traverse 1 and between the two there is approximately a $1.5 \mathrm{~m}$ elevation difference. The two traverses occur on opposite sides of a university surfaced road. Figure 3 displays the inverted electrical resistivity section along $\mathrm{T} 2$. The resistivity response distribution beneath $\mathrm{T} 2$ in a manner similar to that beneath $\mathrm{T} 1$ can be divided into three (3). The first is a basal high resistivity response which extends from an average depth of $7.5 \mathrm{~m}$ beneath the ground surface downwards. This resistivity response pervades the traverse at depth with resistivity values generally greater than $460 \mathrm{ohm}-\mathrm{m}$. Towards the western end of the traverse, this response pattern dips gently until a depth of approximately $10 \mathrm{~m}$. This response pattern is again interpreted to represent the unweathered basement rock in the area. The second pattern is a topmost response pattern of very low resistivity in the range of $88-230 \mathrm{ohm}-\mathrm{m}$. This pattern extends from the surface to a mean depth of $5 \mathrm{~m}$ and its base is relatively flat. The pattern is separated into two segments. A segment extends from the eastern limits of the traverse $(10 \mathrm{~m})$ until position $40 \mathrm{~m}$ as though situated in a wide trough-like depression. The handdug well, which provides water throughout the year, is situated roughly at $37 \mathrm{~m}$ location along this traverse. The other segment is much smaller and occurs at the western limit of the traverse. The two segments are separated by a pattern of moderate resistivity, which emerges from beneath in a dyke-like fashion. This pattern is again interpreted to represent the water saturated clayey aquitard within the area. The third pattern is a response pattern of moderate resistivity, which ranges between 300 and 400 ohm$\mathrm{m}$. This pattern separates the uppermost low resistivity response pattern from the basal high resistivity pattern and lies at an average depth of $7 \mathrm{~m}$ beneath the surfaces. Between positions of $40 \mathrm{~m}$ and $45 \mathrm{~m}$ in the western end of the traverse, this pattern reaches the surface in a thin dyke-like manner and separates the upper low resistivity response into eastern and western segments. This pattern again is interpreted to represent the weathering layer over the fresh basement. The thin vertical dyke-like extension possibly represents more weathering resistant material in the near surface section of the traverse.

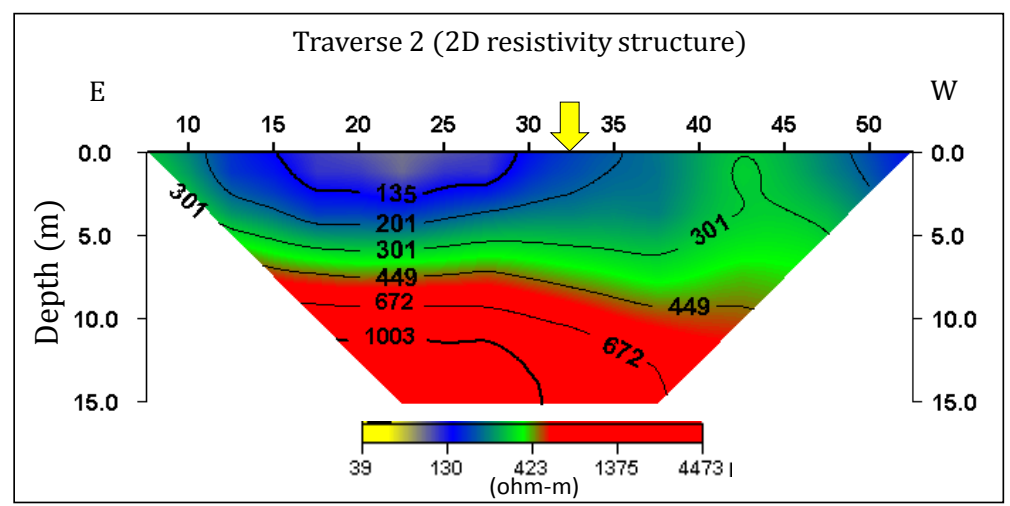

Figure 3. Inverted 2D resistivity structure beneath Traverse 2. The near-surface low resistivity response of the clayey aquitard is segmented into two parts by a more resistant vertical dyke, which extends from below. A perennial hand-hug well (position indicated in yellow arrow) apparently abstracts water from this region.

Traverse 3 (T3) is about $40 \mathrm{~m}$ down-dip and south of traverse 2 and there exists an elevation difference of nearly $7 \mathrm{~m}$ between $\mathrm{T} 2$ and T3. The resistivity structure for $\mathrm{T} 3$ (Figure 4) can in like fashion to $\mathrm{T} 1$ and $\mathrm{T} 2$ be divided into three response patterns. The first pattern is a very high resistivity response pattern with resistivity generally greater than 500 ohm-m.

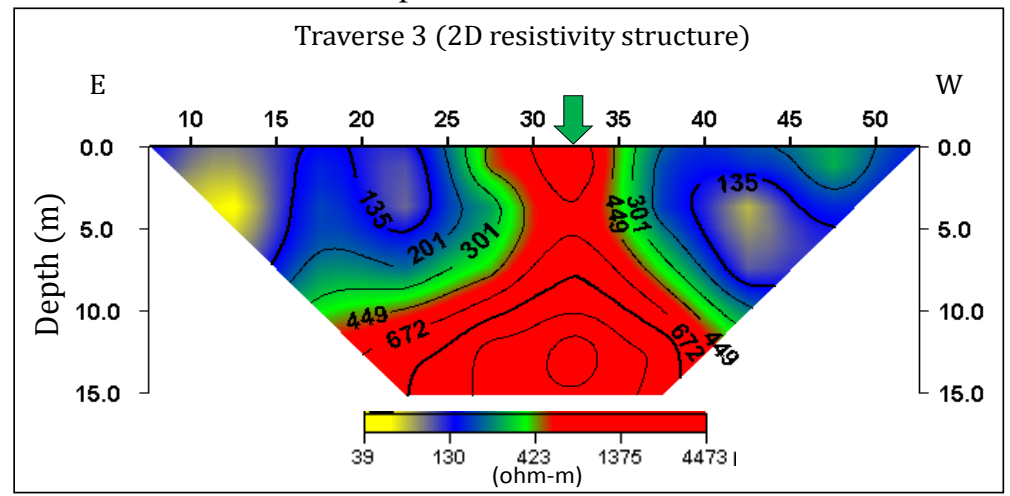

Figure 4. Inverted $2 D$ resistivity structure beneath Traverse 3. Segmentation of the low resistivity response into eastern and western parts is more pronounced as the high resistivity fresh basement response extends all the way to the surface. A university road linking the south campus has been built here (green arrow) taking advantage of this firm ground. 
This pattern occupies both the central and basal parts of the traverse. It is the deepest response pattern between $23 \mathrm{~m}$ and $47 \mathrm{~m}$ along the profile where it takes the shape of a dome from which a dyke-like neck roughly $8 \mathrm{~m}$ thick emerges and extends upwards all the way to the surface. This pattern segments the profile at shallower depths into eastern and western segments with much lower resistivity on either side of the high response dyke. This response pattern is interpreted to represent the unweathered basement rock within the area. Though the basement rock is not visible specifically along the traverse, it can be seen outcropping about $18 \mathrm{~m}$ southwest of T3. The second response pattern consists of very low resistivity patterns with resistivity in the range from 45 to $240 \mathrm{ohm}-\mathrm{m}$. This response pattern is separated into eastern and western segments by the central high resistivity response pattern mentioned above. These segments extend from the surface to an average depth of $8 \mathrm{~m}$ along the profile. The eastern and western limits of the pattern apparently lie beyond the profile length. This pattern is again interpreted to represent the clayey aquitard observed within the study area.
Roughly $35 \mathrm{~m}$ south of $\mathrm{T} 3$, this clayey aquitard develops into open-to-surface densely vegetated muddy swamps. The third pattern consists of intermediate resistivity responses with resistivity between 280 and $450 \mathrm{ohm}-\mathrm{m}$. This pattern occurs as an intermediate pattern between the high resistivity response and the very low resistivity response described previously. This response is once again interpreted to represent the weathering layer around the fresh basement rock. On this traverse, this intermediate response is poorly developed and hardly exceeds a thickness of $1 \mathrm{~m}$.

\section{Discussions}

Figure 5 is a composite fence diagram showing the 2D geo-electric sections discussed earlier. On geoelectric profile $\mathrm{T} 1$, the low resistivity response clayey aquitard is imaged as a thin, generally not greater than $7.5 \mathrm{~m}$ thick layer, which appears to outcrop for most of the traverse at the ground surface.

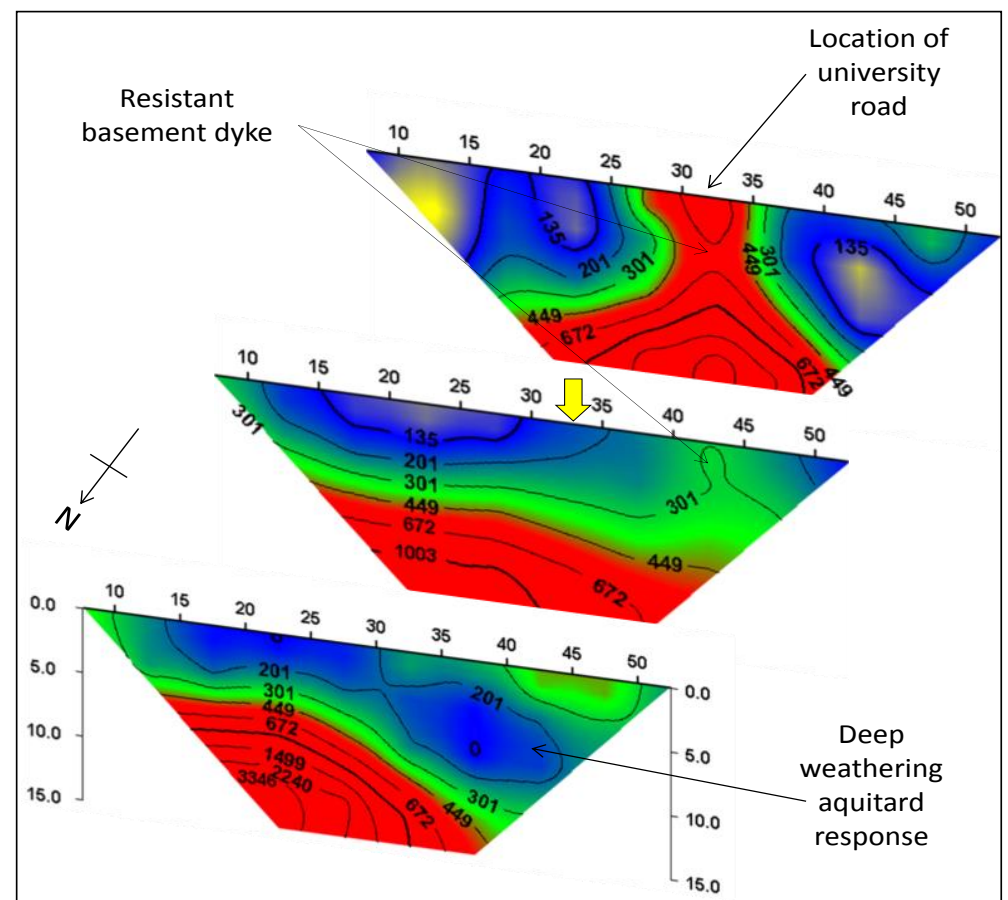

Figure 5. Composite fence plot of all three traverses (viewing approximately from northwest). Northwards, the low resistivity (blue) aquitard response occurs as a single unit but gradually develops into two segments southwards. The apparent basin-like structure of the more weathering resistant basement remains along T2 possibly encourages the storage of ground water for longer periods, allowing the hand-dug well to receive supply allyear-round (Refer to figure 1 for actual spatial separation between the traverse).

At the traverse sight the aquitard is actually covered by very thin humus soil, which has developed as a result of foliage decomposition at the site. In the western extreme of $\mathrm{T} 1$, this aquitard response does to appear at the surface but rather dips downwards from $35 \mathrm{~m}$ at an angle of $33^{\circ}$. On this traverse, the basement rock apparently has suffered deep weathering up to a depth in excess of $10 \mathrm{~m}$ in the western extremes. Further downslope at T2, the aquitard thins and appears to fill into a broad trough- like depression in the resistant bedrock for most of the traverse. The trough results from the occurrence between the position of $40 \mathrm{~m}$ and $45 \mathrm{~m}$ along $\mathrm{T} 2$ of a vertical dyke-like remnant of weathering bedrock. On either side of this more resistant vertical slab, the aquitard has developed. The western extreme of this aquitard response is beyond the coverage of $\mathrm{T} 2$. This aquitard is also covered by very thin topsoil of foliage decomposition origin as along $\mathrm{T} 1$. Beneath this traverse, the depth of weathering is much less than 
along T1. Further downslope at T3, the aquitard response is better developed. It extends from the ground surface to an average depth of $10 \mathrm{~m}$ and possibly to greater depths beyond the eastern and western limits of the profile. The resistant vertical dyke-like basement rock observed along $\mathrm{T} 2$ is better developed along T3 attaining a thickness of roughly $8 \mathrm{~m}$. Further to the south of the profile, this aquitard can be visually seen to develop into muddy densely vegetated swamps containing pinkish clays. During the dry season, the surface clay of this aquitard shrinks and cakes. Here, a university road has been built on the resistant basement rock to link the southern section of the University.

The clays on the University campus are believed to have originated as a result of deep weathering of feldspar and amphibole rich sections of the shallow basement rocks of the area and apparently serve to store and transmit groundwater at very slow rates. This enables it to provide continuous and consistent supply of groundwater albeit at a low rate for longer periods than conventional aquifers in the area and therefore is more reliable during long dry spells. The trough-like depressions surrounding the clayey aquitard particularly along T2 also possibly aid in the storage capacity of the clayey layer by providing a basin-like container which retains recharge for longer periods. For a locale such as the Akungba-Akoko area where regolith development is poor and available streams are highly seasonal, drying up totally during the December to March dry season, a focus on groundwater exploration and development on these sorts of clayey aquitards could provide a major palliative to the acute water supply shortages experienced during the dry season.

\section{Conclusions}

In this study, 2D electrical resistivity imaging technique has been employed to study the nature and development of a thin clayey aquitard on part of the basement complex rocks of the Adekunle Ajasin University campus, Akungba-Akoko south-western Nigeria. The results indicate that the clayey aquitard layer forms in major basement depressions within the area. The depressions possibly result from deep weathering of feldspar and amphibolite rich sections within the fresh bedrock as a result of the preferential channelling and storage of groundwater. More resistant sections of the bedrock serve to compartmentalise and localise the occurrence of this clayey aquitard, and create the structure favourable to groundwater accumulation. Where abundant water is available and the geologic dip of the top of the fresh bedrock is low, the clayey aquitard develops into muddy swamps. With an ever increasing academic population and the attendant increasing water demands, the exploration for and development of these shallow clayey layers in and around the Adekunle Ajasin University campus could prove to be an invaluable source of water supply in the present and the near future.

\section{Acknowledgements}

I am grateful to Mr. O. A. Ishola, formerly of the Department of Earth Sciences, Adekunle Ajasin University, Akungba-Akoko, Nigeria, for cartographic support.

\section{References}

Aminu, M. B., Ajayi, O. O., \& Adelabu, O.G. (2014a) Geochemical Analyses of Domestic Groundwater Sources in Okeagbe-Akoko, South-western Nigeria. Journal of Applied Geology and Geophysics 2(2): 2934. http://dx.doi.org/10.9790/0990-02212934

Aminu, M. B., Akande, T. M., \& Ishola, O. A. (2014b). 2D geoelectric imaging of the Uneme-nekhua fracture zone. Journal of Geophysics, 2014. http://dx.doi.org/10.1155/ $\underline{2014 / 842812}$

Bello, O. B., Ganiyu, O. T., Wahab, M. K. A., Afolabi, M. S., Oluleye, F., Ig, S. A., Mahmud, J., Azeez, M. A., \& Abdulmaliq, S. Y. (2012). Evidence of climate change impacts on agriculture and food security in Nigeria. International Journal of Agriculture and Forestry, 2(2), 49-55.

Frid, V., Liskevich, G., Doudkinski, D., \& Korostishevsky, N. (2007) Evaluation of landfill disposal boundary by means of electrical resistivity imaging. Environmental Geology, 53(7), 1503-1508. http://dx.doi.org/10.1007/ s00254-007-0761-3

Hamil, L. \& Bell, F. G. (1986) Groundwater Resource Development (p. 344). London: Butterworths. http://dx.doi.org/10.1016/B978-0-408-01409-0.50004-0

LaBrecque, D. J., Ramirez, A. L., Daily, W. D., Binley, A. M., \& Schima, S. A. (1996). ERT monitoring of environmental remediation processes. Measurement Science and Technology, 7, 375-383. http://dx.doi.org/ $\underline{10.1088 / 0957-0233 / 7 / 3 / 019}$

Lines, J. P., Bernardes, S., He, J., Zhang, S., Bacchus, S. T., Madden, M., \& Jordan, T. (2012). Preferential groundwater flow pathways and hydroperiod alterations indicated by geo-rectified lineaments and sinkholes at proposed karst nuclear power plant and mine sites. Journal of Sustainable Development, 5(12), 78-116. http://dx.doi.org/10.5539/jsd.v5n12p78

Loke, M. H. (2000). Electrical imaging surveys for environmental and engineering studies: A practical guide to 2-D and 3-D surveys (p. 61). Retrieved from: http://www.heritagegeophysics.com/images/lokenote.pd $\underline{f}$

Mohamed, N. E., Brasse, H., Abdelgalil, M. Y., \& Kheiralla, K. M. (2012). Geoelectric and VLF electromagnetic survey on complex aquifer structures, Central Sudan. Comunicações Geológicas, 99(2), 95100.

Moustafa, S. S. R., Ibrahim, E. H., Elawadi, E., Metwaly, M., \& Al Agami, N. (2012). Seismic refraction and resistivity imaging for assessment of groundwater seepage under a Dam site, Southwest of Saudi Arabia. International Journal of the Physical Sciences, 7(48), 6230-6239.

Nguyen, F., Garambois, S., Jongmans, D., Pirard, E., \& Loke, M. H. (2005). Image processing of 2D resistivity data for imaging faults. Journal of Applied Geophysics, 57, 260-277. http://dx.doi.org/10.1016/j.jappgeo. $\underline{2005.02 .001}$ 
Nwankwoala, H. O. (2011). An integrated approach to sustainable groundwater development and management in Nigeria. Journal of Geology and Mining Research, 3(5), 123-130.

Offodile, M. E. (1983). The occurrence and exploitation of groundwater in Nigeria basement rocks. Journal of Mining and Geology, 4, 131-146.

Rahaman, M. A. (1989). Review of the Basement Geology of South-Western Nigeria. In: Kogbe, C. A. (eds.). Geology of Nigeria (2 ${ }^{\text {nd }}$ ed.) (pp. 39-56). Rockview Nige Limited, Jos.

Reynolds, J. M. (1997). An Introduction to Applied and Environmental Geophysics (p. 796). West Sussex, England: John Wiley and Sons Ltd.

Rizzo, E., Colella, A., Lapenna, V., \& Piscitelli, S. (2004). High-resolution images of the fault-controlled High Agri-Valley basin (Southern Italy) with deep and shallow electrical resistivity tomographies. Physical Chemistry of the Earth, 29, 321-327. http://dx.doi.org/ 10.1016/j.pce.2003.12.002

Robineau, B., Join, J. L., Beauvais, A., Parisot, J-C., \& Savin, C. (2007). Geoelectrical imaging of a thick regolith developed on ultramafic rocks: groundwater influence. Australian Journal of Earth Sciences, 54(5), 773-781. http://dx.doi.org/10.1080/08120090701305277

Sjödahl, P., Dahlin, T., Zhou, B., \& Johansson, S. (2002). Monitoring of leakage in embankment dams through resistivity measurements - A $2.5 \mathrm{D}$ modelling study. In: Proceedings of the $8^{\text {th }}$ Meeting Environmental and Engineering Geophysics (pp. 169-172), 8-12 September 2002, Aveiro, Portugal.

Telford, W. M., Geldart, L. P., Sheriff, R. E., \& Keys, D. A. (1990). Applied Geophysics ( $2^{\text {nd }}$ ed.) (p. 770). Cambridge: University Press. http://dx.doi.org/10.1017/ CBO9781139167932

Todd, D. K. (1980). Groundwater Hydrology (2 ${ }^{\text {nd }}$ ed.) (p. 535). John Wiley and Sons Ltd.

Venkateswarlu, G., Jayasankar, G., \& Saradhi, B. V. (2014). Impact assessment of land use change on ground water quality using remote sensing \& GIS for zone V under municipal corporation hyderabad. IOSR Journal of Mechanical and Civil Engineering, 11(1), 36-42. http://dx.doi.org/10.9790/1684-11153642

White, R. M. S., Collins, S., \& Loke, M. H. (2003). Resistivity and IP arrays, optimised for data collection and inversion. Exploration Geophysics, 34, 229-232. http://dx.doi.org/10.1071/EG03229

Yi, M. J. \& Kim, J.H. (1998). Enhancing the resolving power of the least squares inversion with Active Constraint Balancing. In: SEG Expanded Abstracts, 68 Annual Meeting (pp. 485-488). New Orleans. http://dx.doi.org/10.1190/1.1820469

Zume, J. T., Tarhule, A., \& Cristenson, S. (2006). Subsurface imaging of an abandoned solid waste landfill site in Norman, Oklahoma. Ground Water Monitoring and Remediation, 25(2), 62-69. http://dx.doi.org/10.1111/j.1745-6592.2006.00066.x 


\title{
Plonos pusiau laidžios molingos uolienos, susidariusios ant pagrindinès uolienos Adekunle Ajasin universiteto studentụ miestelio vietovẻje, Akungba-Akoko, pietvakariụ Nigerijoje, elektrinès varžos vaizdavimas
}

\author{
Muslim B. Aminu
}

Žemès mokslų katedra, Adekunle Ajasin universitetas, Akungba-Akoko, Nigerija

(gauta 2014 m. gruodžio mèn.; priimta spaudai 2015 m. kovo mėn.)

Siekiant nustatyti plonos pusiau laidžios molingos uolienos, esančios ant pamatinių kompleksinių uolienų pietvakarių Nigerijoje, Akungba-Akoko, Adekunle Ajasin universiteto studentų miestelyje, prigimtį ir vystymąsi, šiame tyrime 2D metodu buvo stebima savitoji elektrinè varža. Tyrimo tikslas buvo îvertinti slūgsojimą, geometriją ir gruntinio vandens tiekimo, kaip alternatyvaus vandens tiekimo studentų miesteliui, igyvendinamumą. Prieš tai rankiniu būdu iškastas šulinys, iš kurio buvo tiekiami vidutiniai vandens kiekiai ištisus metus traukiant vandenị iš šios pusiau laidžios molingos uolienos.

Trys rytų-vakarų kryptimis nukreipti geoelektriniai skersiniai buvo stebimi naudojant dipolines matricų konfigūracijas su $5 \mathrm{~m}$ tarpusavyje atskirtais elektrodais ir didžiausiu dipoliniu ilgiu, siekiančiu $45 \mathrm{~m}$. Kiekvienas iš trijų skersinių buvo $60 \mathrm{~m}$ ilgio. Stebimi tyrimo vietos duomenys buvo invertuoti paviršinio sluoksnio 2D savitosios varžos struktūromis, naudojant komerciškai prieinamą 2,5D baigtinių elementų modeliavimo programavimo įrangą. Gauti vaizdai parodè, kad pusiau laidi molinga uoliena egzistuoja kaip mažos varžos atsako raštai. Šie raštai atsirado pailguose lovelio tipo įdubimuose, atsiradusiuose dèl smarkios lauko špato erozijos ir amfibolitų turtingų pagrindinių uolienų dalių.

Šis molingas sluoksnis pasiekia $10 \mathrm{~m}$ storị tyrimo teritorijos pietineje dalyje, ir kai kuriose dalyse jis suskirstytas i segmentus dèl pagrindinès uolienos, kuri atsparesnè erozijai. Kur topografinis žemės paviršiaus šlaitas yra pakankamai mažas, kad leistų nutekančio vandens kaupimąsi, pusiau laidus molingas sluoksnis virsta i matomas pelkètas balas. Nors tokio tipo pusiau laidžia molinga uoliena vanduo tiekiamas nedideliais kiekiais, jų galimybès saugoti didelius kiekius vandens ir duoti naudos ištisus metus galètų pagrịsti būtinumą gerinti padèti dèl vandens trūkumo tiriamoje vietovèje sausuoju sezonu.

Raktiniai žodžiai: Akungba-Akoko, pusiau laidi molinga uoliena, elektrinès varžos vaizdavimas, smarkios erozijos latakai. 